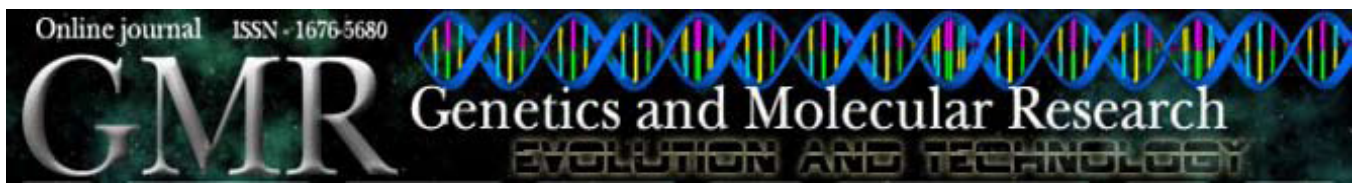

\title{
IGF-I gene polymorphism, but not its blood concentration, is associated with milk fat and protein in Holstein dairy cows
}

\author{
E. Bonakdar ${ }^{1}$, H.R. Rahmani ${ }^{1}$, M.A. Edriss ${ }^{1}$ and B.E. Sayed Tabatabaei ${ }^{2}$ \\ ${ }^{1}$ Department of Animal Science, College of Agriculture, \\ Isfahan University of Technology, Isfahan, Iran \\ ${ }^{2}$ Department of Biotechnology, College of Agriculture, \\ Isfahan University of Technology, Isfahan, Iran
}

Corresponding author: H.R. Rahmani

E-mail: hrahmani@cc.iut.ac.ir

Genet. Mol. Res. 9 (3): 1726-1734 (2010)

Received April 12, 2010

Accepted June 24, 2010

Published August 31, 2010

DOI 10.4238/vol9-3gmr874

\begin{abstract}
We estimated the allele and genotype frequencies of IGF-I/SnaBI gene polymorphism and the concentration of this protein in Holstein dairy cows. We also examined the association with milk yield (305-day milk yield) and milk components (fat and protein percentage, and 305-day milk protein and fat yield). Blood IGF-I levels were measured and genotyping was performed on 250 Holstein cows of four different herds. In the association studies, traits of interest were analyzed using the GLM procedure of SAS; means of the IGF-I level among genotypes were compared by the LSMeans test. The $\mathrm{AB}$ and $\mathrm{AA}$ genotypes were the most $(0.583-0.661)$ and least (0.083-0.192) frequent in the herds, respectively; the frequency of the BB genotype ranged from 0.201 to 0.333 . The frequency of the A allele ranged from 0.375 to 0.495 , while the frequency of the $\mathrm{B}$ allele ranged from 0.504 to 0.625 , being the dominant allele. The mean level of IGF-I was $107 \pm 22 \mathrm{ng} / \mathrm{mL}$ for all groups, without
\end{abstract}


any significant correlation with the production traits. Association of IGF-I/SnaBI genotypes with percentage of fat and protein in the milk was relatively high $(\mathrm{P}<0.1$ and $\mathrm{P}<0.05$, respectively); the $\mathrm{AB}$ genotype was superior to AA and BB genotypes. We concluded that this marker should be considered for milk component selection in Holstein dairy cattle.

Key words: Dairy Holstein; Gene polymorphism; Milk protein; Milk fat; IGF-I

\section{INTRODUCTION}

Progress in molecular biology and genetic technology has created much interest in the possible use of somatomedin signal transduction level or DNA-based diagnostic tests to evaluate and predict production, and to enhance strategies for genetic improvement of livestock. It is believed that marker-assisted selection (MAS), as a new and efficient tool, will increase the annual rate of genetic gain in livestock by 15 to $30 \%$, and decrease the risk in breeding schemes (Kashi et al., 1990; Meuwissen and Van Arendonk, 1992). In this model, the expected genetic gain with MAS is estimated to range from 44.7 to $99.6 \%$ (Edwards and Page, 1994). Gene mapping research has led to the discovery of many polymorphic sites throughout the cattle genome that can serve as genetic markers and that are related to productive traits; these have been used for beef cattle selection (Moore et al., 2005; Huang et al., 2006; Pagan et al., 2006; Ribeiro et al., 2007). However, relatively little is known about relationships between specific markers and production traits in dairy cattle. Polymorphic sites in genes involved in the mediation of growth factors are logical candidates for studies of possible associations with livestock production traits. Candidate genes should have known biological functions related to the development or physiology of an important trait. Generally, polymorphism of the gene will affect gene expression by changing RNA splicing and stability, rate and regulation of gene transcription, or the amino acid sequence of the gene product. In this case, dairy cattle genes involved in milk production and milk components are particularly relevant (Grosclaude, 1988; $\mathrm{Ng}$-Kwai-Hang and Grosclaude, 1992; Jakob, 1994). The somatotrophic axis is a well-known mechanism that essentially consists of growth hormone releasing hormone (GHRH), growth hormone (GH), insulin-like growth factor I and II (IGF-I and IGF-II), and their associated binding proteins and receptors; this sytem regulates the metabolism and physiology of mammalian growth. Long-term use of recombinant GH in dairy farms has confirmed the key role of the somatotrophic axis in this physiological function (Bauman, 1999; Baldi, 1999). IGF-I is a well-known somatomedin (Sorensen et al., 1992; Renaville, 1997; Curi et al., 2005); it is expressed by a gene located on chromosome 5 that shows an SnaBI polymorphysm in the 5' flanking region (Miller et al., 1992; Ge et al., 1997). Parmentier et al. (1999) reviewed the somatotrophic axis and its relationship with milk production and selection; this pathway and particularly IGF-I, the 7649-Da single-chain peptide and its gene, appear to be promising for association with reproductive traits in Angus beef cattle (Yilmaz et al., 2004). Based on these considerations, we evaluated blood IGF-I levels and estimated allele and genotype frequencies of IGF-I gene polymorphism in Holstein cows, and examined associations between this polymorphism and milk production, as well as with milk components. 


\section{MATERIAL AND METHODS}

\section{Animals}

For this experiment, blood was collected in the early morning from 250 multiparous $(\mathrm{N}<4)$ Holstein cows, 60 days postpartum, randomly selected among 2150 cows from four dairy herds in Isfahan province. Accurate recorded data were available for these cows and no metabolic disorders were reported. Twenty milliliters blood was collected in vacuum venoject tubes with EDTA; $5 \mathrm{~mL}$ was centrifuged at $7000 \mathrm{~g}$ for $15 \mathrm{~min}$ and the serum stored at $-20^{\circ} \mathrm{C}$ for IGF-I evaluation. The rest of the whole blood was stored in $5-\mathrm{mL}$ tubes at the same temperature for DNA extraction. Accurate recorded data for four to five years for each cow was also used for data analysis of the production parameters.

\section{Marker genotype determination and blood IGF-I evaluation}

Genomic DNA was extracted from the whole blood using the salting out method (Miller et al., 1988). The IGF-I genotypes were identified with the polymerase chain reactionrestriction fragment length polymorphism (PCR-RFLP) technique. PCR was used to amplify the 249-bp DNA fragments from genomic DNA. PCR contained 25-50 ng genomic DNA, 10 pmoL of each primer, $2 \mu \mathrm{L} 10 \mathrm{X}$ PCR buffer, $1.5 \mathrm{mM} \mathrm{MgCl}, 200 \mu \mathrm{M}$ dNTP and 1 unit Taqpolymerase, in a total volume of $20 \mu \mathrm{L}$. Sequences of the primers that were used in PCR were reported previously by Ge et al. (2001). Sequences of IGFR and IGFF were 5'-CCT TAC CCG TAT GAA AGG AAT ATA CGT-3' and 5'-ATT ACA AAG CTG CCT GCC CC-3', respectively. Conditions for PCR were $97^{\circ} \mathrm{C}$ for $2 \mathrm{~min}$, followed by 31 cycles of $94^{\circ} \mathrm{C}$ for $60 \mathrm{~s}$, $58^{\circ} \mathrm{C}$ for $45 \mathrm{~s}$, and $72^{\circ} \mathrm{C}$ for $60 \mathrm{~s}$. The final step was at $72^{\circ} \mathrm{C}$ for $5 \mathrm{~min}$. Eight microliters PCR products was digested with five units of SnaBI (Fermentas Co.) in $20 \mu \mathrm{L}$ of reaction volume at $37^{\circ} \mathrm{C}$ for $4 \mathrm{~h}$ for RFLP of the IGF-I gene. The digested products plus $2 \mu \mathrm{L}$ loading dye were run on $2 \%$ agarose gel for $2 \mathrm{~h}$, and the genotype bands were visualized under UV light. The blood sera were analyzed for IGF-I concentration with the method developed for cattle (Davis and Simmen, 1997).

\section{Statistical analysis}

For the association studies, the traits of interest were analyzed using the general linear model (GLM) procedure of the SAS program (Statistical Analysis System, 1997), and the least square means of the genotypes were compared by the LSMeans test. The linear model used to fit the quantitative variables was included, in addition to the genotype effect:

$$
\mathrm{Y}_{i j k}=\mu+\mathrm{I}_{i}+\mathrm{H}_{j}+\mathrm{b}_{1}\left(\mathrm{X}_{i j k}-\mathrm{X}\right)+\mathrm{b}_{2}\left(\mathrm{Z}_{i j k}-\mathrm{Z}\right)+\mathrm{b}_{3}\left(\mathrm{~W}_{i j k}-\mathrm{W}\right)+\mathrm{e}_{i j k}
$$

where $\mathrm{Y}_{i j k}=$ production trait, $\mu=$ overall mean, $\mathrm{I}_{i}=$ fixed effect of the $i$ th genotype (AA, AB and $\mathrm{BB}), \mathrm{H}_{j}=$ fixed effect of the $j$ th herd $(1,2,3$, and 4$), \mathrm{X}_{i j k}=$ days of milking, $\mathrm{b}_{1}=$ the linear regression coefficient of days of milking, $Z_{i j k}=$ a vector of dry days, $b_{2}=$ the linear regression coefficient of dry days, $\mathrm{W}_{i j k}=$ open days, $\mathrm{b}_{3}=$ the linear regression coefficient of open days, and $\mathrm{e}_{i j k}=$ the random error. 


\section{RESULTS}

\section{Marker genotyping and blood IGF-I level}

The A and B alleles of the IGF-I gene were identified based on amplification of a 249-bp fragment located in the regulatory region of the gene, $512 \mathrm{bp}$ upstream of the initiation codon, followed by digestion with the restriction enzyme SnaBI (Figure 1). Two genetic variants (A and B) of the IGF-I polymorphism were observed in this experiment. Genotype AA was characterized by two restriction fragments of 226 and $23 \mathrm{bp}$, while genotype BB was determined by the presence of a single 249-bp fragment. AB individuals presented three fragments of 249, 226, and $23 \mathrm{bp}$. The 226-bp fragment and the whole fragment (249 bp) were clearly visible, while the 23-bp fragment migrated to the base of the gel.

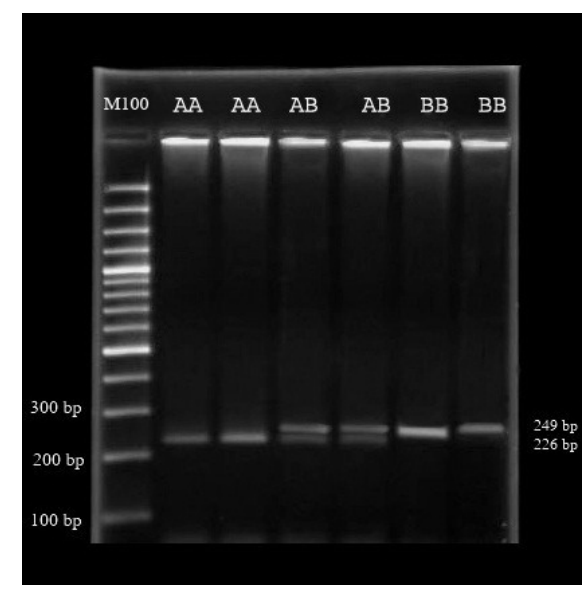

Figure 1. Mini-agarose gel stained with ethidium bromide and viewed under UV light. From left to right; lane $1=$ molecular size markers; lanes 2 and 3 =AA genotype (226 bp); lanes 4 and $5=\mathrm{AB}$ genotype (226 and $249 \mathrm{bp}$ ), and lanes 6 and $7=\mathrm{BB}$ genotype $(249 \mathrm{bp})$. The 23-bp fragment is undetectable and moved away from the base of the gel.

The $\mathrm{AB}$ and $\mathrm{AA}$ genotypes were the most and least frequent in all herds, respectively (Table 1). The frequency of the A allele ranged from 0.375 to 0.495 and the frequency of the $\mathrm{B}$ allele ranged from 0.504 to 0.625 ; they are in Hardy-Weinberg equilibrium.

Blood analysis for IGF-I level showed no significant differences between groups, with a mean of $107 \pm 22 \mathrm{ng} / \mathrm{mL}$.

\begin{tabular}{|c|c|c|c|c|c|c|}
\hline \multirow[t]{2}{*}{$\overline{\text { Herd }}$} & \multirow[t]{2}{*}{$\mathrm{N}$} & \multicolumn{3}{|c|}{ Genotypes } & \multicolumn{2}{|c|}{ Alleles } \\
\hline & & AA & $\mathrm{AB}$ & $\mathrm{BB}$ & $\mathrm{A}$ & $\mathrm{B}$ \\
\hline $1 \mathrm{st}$ & 56 & 0.089 & 0.661 & 0.250 & 0.420 & 0.580 \\
\hline 2nd & 54 & 0.130 & 0.630 & 0.241 & 0.444 & 0.556 \\
\hline $3 \mathrm{rd}$ & 36 & 0.083 & 0.583 & 0.333 & 0.375 & 0.625 \\
\hline 4th & 104 & 0.192 & 0.605 & 0.201 & 0.495 & 0.504 \\
\hline Total/Average & 250 & 0.142 & 0.630 & 0.227 & 0.457 & 0.542 \\
\hline \multicolumn{2}{|c|}{ Expected Hardy-Weinberg equilibrium } & 0.208849 & 0.495388 & 0.293764 & \multicolumn{2}{|c|}{$\chi^{2}=17.2845^{*}$} \\
\hline
\end{tabular}

$* \chi^{2}$ probability $=0.0002 ;$ d.f. $=2$. 


\section{Association analysis}

All three genotypes were considered to be in the association analysis between IGF-I/ SnaBI polymorphism genotypes and production traits. Milk production differed among the three groups $(\mathrm{P}<0.1)$, but the corrected milk production for 305 days did not differ among the groups ( $\mathrm{P}>0.1$; Table 2). Genotype AA had the highest and BB the lowest production, while $\mathrm{AB}$ was intermediate for $\mathrm{kg} / \mathrm{year}$ milk production. There was an association between genotypes and fat and protein content of the milk (Table 3). Genotypes AA and BB had lower milk fat than the $A B$ group $(P<0.1)$. Similar results were found for milk protein concentration, with the highest production for the $\mathrm{AB}$ type and the lowest for $\mathrm{AA}$ and $\mathrm{BB}$ groups $(\mathrm{P}<0.05)$. Corrected total fat and protein produced over the year (305 days; Table 4) was also the highest for the $\mathrm{AB}$ group $(\mathrm{P}<0.1)$.

Table 2. Least square means and standard error (LSMean \pm SE) of the milk yield $(\mathrm{kg})$ trait obtained from
different genotypes of IGF-I/SnaBI polymorphisms in Holstein dairy cows.
\begin{tabular}{lcccc}
\hline Polymorphism & Genotype & $\mathrm{N}$ & Milk (kg/year) & 305-day milk yield $(\mathrm{kg})$ \\
\hline IGF-I/SnaBI & AA & 35 & $10,982 \pm 247^{\mathrm{a}}$ & $8,753 \pm 190^{\mathrm{a}}$ \\
& $\mathrm{AB}$ & 155 & $10,655 \pm 119^{\mathrm{ab}}$ & $8,591 \pm 91^{\mathrm{a}}$ \\
& $\mathrm{BB}$ & 60 & $10,444 \pm 179^{\mathrm{b}}$ & $8,525 \pm 135^{\mathrm{a}}$ \\
\hline
\end{tabular}

Different superscript letters in each column indicate significant differences $(\mathrm{P}<0.1)$.

Table 3. Least square means and standard errors (LSMean \pm SE) of the milk traits (fat and protein percent) obtained from different genotypes of the IGF-I/SnaBI polymorphism gene in Holstein dairy cows.

\begin{tabular}{lcccc}
\hline Polymorphism & Genotype & N & Fat (\%) & Protein (\%) \\
\hline IGF-I/SnaBI & AA & 35 & $2.55 \pm 0.06^{\mathrm{b}}$ & $2.61 \pm 0.09^{\mathrm{b}}$ \\
& AB & 155 & $2.67 \pm 0.03^{\mathrm{a}}$ & $2.83 \pm 0.04^{\mathrm{a}}$ \\
& BB & 60 & $2.57 \pm 0.04^{\mathrm{b}}$ & $2.70 \pm 0.06^{\mathrm{b}}$ \\
& & $\mathrm{P}<0.1$ & $\mathrm{P}<0.05$ \\
\hline
\end{tabular}

Regarding the $\mathrm{P}$ value, numbers with the same superscript letters in each column are not significantly different.

Table 4. Least square means and standard error $(\mathrm{LSMean} \pm \mathrm{SE})$ of the milk yield trait ( $\mathrm{kg}$ fat and protein/305 days) obtained from different genotypes of the IGF-I/SnaBI polymorphism gene in Holstein dairy cows.

\begin{tabular}{lcccc}
\hline Polymorphism & Genotype & $\mathrm{N}$ & 305-day milk fat $(\mathrm{kg})$ & 305-day milk protein $(\mathrm{kg})$ \\
\hline IGF-I/SnaBI & AA & 35 & $217.0 \pm 10.1^{\mathrm{ab}}$ & $217.7 \pm 12.3^{\mathrm{b}}$ \\
& AB & 155 & $229.6 \pm 5.1^{\mathrm{a}}$ & $245.3 \pm 5.2^{\mathrm{a}}$ \\
& BB & 60 & $214.0 \pm 7.4^{\mathrm{b}}$ & $238.7 \pm 7.5^{\mathrm{ab}}$ \\
\hline
\end{tabular}

$\mathrm{a}, \mathrm{b}=$ significantly different least square means $(\mathrm{P}<0.1)$.

\section{DISCUSSION}

The PCR-RFLP method was useful for IGF-I genotype marking and could be useful for selection in dairy cattle. It could be used for genotyping to distinguish candidate alleles, as the gene loci are conserved among the breeds. In earlier studies (Kirkpatrick, 1992; Ge et al., 1997) of a dinucleotide repeat polymorphism in the 5 flanking region of the IGF-I gene in cattle and swine, a possible role of this somatomediater in production traits was evident. There have been studies of the allelic frequency of IGF-I gene in different cattle breeds, and beef cattle is considered to be a model for this system (Ge et al., 2001; Spicer et al., 2002; 
Curi et al., 2005). The primers that we used are similar to those used by Ge et al. (2001), who determined that IGF-I polymorphism is a $\mathrm{T}$ (allele A) for $\mathrm{C}$ (allele $\mathrm{B}$ ) transition located in the regulatory region of the IGF-I gene that can directly or indirectly affect production traits. In other words, this marker can affect phenotypic traits or be in disequilibrium linkage with polymorphisms affecting traits (Ge et al., 2001). In Angus cattle, these primers produced a frequency of 0.64 for the A allele and 0.36 for the B allele (Ge et al., 2001). Synthetic Canchim breed (5/8 Charolais $+3 / 8 \mathrm{Zebu})$ and cows from Simmental and Angus sires and Nellore dams, have low frequencies of the A allele $(0.35,0.2$ and 0.32 , respectively) compared to the B allele (Curi et al., 2005; Pereira et al., 2005). In our study, similar frequencies were obtained for the two alleles $(\mathrm{B}$ allele $=0.542$; A allele $=0.463$ ).

The correlation found between blood IGF-I levels and genotype in earlier studies (Ge et al., 2001; Spicer et al., 2002) was not found here. This could be due to selection of the meat breed using this factor as a selection index (Yilmaz et al., 2004; Huang et al., 2006; Pagan et al., 2006; Ribeiro et al., 2007), which was not done for these dairy cattle. The association between blood IGF-I levels and IGF-I polymorphism in beef cattle could be used for selection criteria. However, there is no correlation between genotype and somatomedin concentration in dairy cattle (Parmentier et al., 1999), though they have the same polymorphism found in beef breeds. Another important point that should be considered is the timing of blood sampling and IGF-I evaluation on day 60 after parturition. There is a critical point involving the role of the hormones, somatomedins and cytokines that have different concentrations and roles according to physiological circumstances, sampling time and even age (Ge et al., 2001; Spicer et al., 2002; Rietveld et al., 2003). One crucial point might be the time of sampling, or even more physiologically complicated is the fact that dairy cattle at lactation time have their own local IGF-I molecule concentration in the mammary gland, rather than just the general circulation level (Cohick, 1998; Weber et al., 2000; Hadsell et al., 2002; Marshman and Streuli, 2002).

As the blood level of IGF-I was not correlated with its relevant allele genotype, the finding of an association of gene polymorphism and production traits was surprising and different from what was expected. The role of IGF-I and its binding proteins has been reviewed (Sara and Hall, 1990; Jones and Clemmons, 1995); IGF-I mediates cell proliferation and is essential for normal development of the mammary gland during puberty and pregnancy (Marshman and Streuli, 2002). Most studies of beef cattle have revealed an association between gene polymorphism and body condition scoring and weight, particularly in early life stages (Ge et al., 2001; Spicer et al., 2002; Curi et al., 2005; Pereira et al., 2005). Significant relationship between milk production and gene character, and a different pattern for corrected 305-day milk productions implies an important physiological role of this somatomedin in other parts of the body. This could involve the reproductive system, which affects open days and can prolong calving intervals. On the other hand, dairy cattle have been selected for milk production over many years, and the mammary gland as an independent organ involved in milk synthesis may respond differently from beef cattle in blood IGF-I levels. Beef cattle use the general circulatory IGF-I synthesized in the liver for muscular growth, but the mammary gland is able to produce this somatomedin locally as well, and preferably use it for milk synthesis. It would be interesting to compare beef and dairy cattle in milk synthesis physiology and examine the association with IGF-I level. The contradictions found can be explained by a lack of standardization in the sampling process, since great variations exist in plasma IGF-I concentration among species, breeds, ages, physiological states, and nutritional status. 
We demonstrated an association between the $\mathrm{AB}$ genotype and higher percentage of milk fat and protein. The bovine chromosome 5 harbors quantitative trait loci close to the IGFI gene location, influencing various phenotypic production traits and body conditioning as well (Machado et al., 2003). This gene in different breeds may affect different characteristics in the same species, depending on the selection program. It is clear that the somatotrophin axis affects many physiological activities, particularly milk production in dairy cattle (Collier et al., 2008). Until now, there has been no information about correlations between milk fat and protein content, and blood or milk IGF-I concentration, and no one had analyzed five years of quantitative information to evaluate its association with gene polymorphism in dairy cattle. There is just a preliminary report that indirectly confirms the effect of this somatomediater on protein synthesis in bovine mammary secretory cells (Hanigan et al., 1992). This demonstrates a possible role of IGF-I on milk protein synthesis in the bovine mammary gland. Protein and lipid metabolism and their secretion in the milk in different species need more research. Another hypothesis to explain the association results that we obtained is that this polymorphism indirectly affects production traits by being in linkage disequilibrium with another polymorphism that directly influences the quantitative traits that we analyzed. This hypothesis is supported by the fact that various other genes are located close to the IGF-I gene on bovine chromosome 5; these genes are known to influence growth and tissue differentiation and may be candidate genes for these traits (Kirkpatrick, 1992; Ge et al., 1997; Cohick, 1998; Parmentier et al., 1999; Machado et al., 2003). We conclude that long-term data are a convenient tool for tracing productive associations. The relationship between milk production data, milk fat and protein content with IGF-I gene polymorphism involves a combination of quantitative and qualitative genetic surveys. The presence of a gene or allele is different from gene expression; expression is dependent on environmental circumstances. Ge et al. (2001) proposed that expression levels of alleles of the IGF-I gene are mediated by differences in transcriptional activity, and that this activity is dependent on many unknown parameters. Studies analyzing the transcriptional activity of polymorphic promoters using a reporter gene in a cell culture transient expression assay would help establish whether the IGF-I/SnaBI polymorphism is responsible for the alterations in the expression pattern of the IGF-I gene. This polymorphism could have a significant effect on gene expression patterns through the modification of DNAprotein interaction sites. In conclusion, we showed that dairy cattle IGF-I gene polymorphism is distinguishable by examining IGF-I/SnaBI, and that this polymorphism is correlated with milk production and milk components. The AB genotype of IGF-I/SnaBI polymorphism can be selected for genetic gains in fat and protein percentages. Further studies using in vitro biological analysis should be conducted in order to check the effects of this polymorphism on the expression pattern of the IGF-I gene.

\section{ACKNOWLEDGMENTS}

The authors thank the Isfahan University of Technology for a grant and financial support of E. Bonakdar's MSc. thesis research.

\section{REFERENCES}

Baldi A (1999). Manipulation of milk production and quality by use of somatotropin in dairy ruminants other than cow. Domest. Anim. Endocrinol. 17: 131-137. 
Bauman DE (1999). Bovine somatotropin and lactation: from basic science to commercial application. Domest. Anim. Endocrinol. 17: 101-116.

Cohick WS (1998). Role of the insulin-like growth factors and their binding proteins in lactation. J. Dairy Sci. 81: 17691777.

Collier RJ, Miller MA, McLaughlin CL, Johnson HD, et al. (2008). Effects of recombinant bovine somatotropin (rbST) and season on plasma and milk insulin-like growth factors I (IGF-I) and II (IGF-II) in lactating dairy cows. Domest. Anim. Endocrinol. 35: 16-23.

Curi RA, Oliveira HN, Silveira AC and Lopes CR (2005). Effects of polymorphic microsatellites in the regulatory region of IGF1 and GHR on growth and carcass traits in beef cattle. Anim. Genet. 36: 58-62.

Davis ME and Simmen RC (1997). Genetic parameter estimates for serum insulin-like growth factor I concentration and performance traits in Angus beef cattle. J. Anim. Sci. 75: 317-324.

Edwards MD and Page NJ (1994). Evaluation of marker-assisted selection through computer simulation. Theor. Appl. Genet. 88: 376-382.

Ge W, Davis ME and Hines HC (1997). Two SSCP alleles detected in the 5'-flanking region of bovine IGF1 gene. Anim. Genet. 28: 155-156.

Ge W, Davis ME, Hines HC, Irvin KM, et al. (2001). Association of a genetic marker with blood serum insulin-like growth factor-I concentration and growth traits in Angus cattle. J. Anim. Sci. 79: 1757-1762.

Grosclaude F (1988). The genetic polymorphism of the main bovine lactoproteins. Relationships with milk yield, composition, and cheese yielding capacity. INRA Prod. Anim. 1: 5-17.

Hadsell DL, Bonnette SG and Lee AV (2002). Genetic manipulation of the IGF-I axis to regulate mammary gland development and function. J. Dairy Sci. 85: 365-377.

Hanigan MD, Choi J, Calvert CC and Baldwin RL (1992). Effects of IGF = I on rates of growth and milk protein production by bovine mammary secretory cells. FASEB J. 6: A1116.

Huang WC, Hines HC and Davis ME (2006). Estimation of genetic trend in IGF-I concentration and correlated response in growth traits in lines of Angus beef cattle divergently selected for serum IGF-I concentration. J. Anim. Sci. 84 (Suppl 2): 109-110.

Jakob E (1994). Genetic polymorphism of milk proteins. Bull. Int. Dairy Fed. 298: 17-27.

Jones JI and Clemmons DR (1995). Insulin-like growth factors and their binding proteins: biological actions. Endocr. Rev. 16: 3-34.

Kashi Y, Hallerman E and Soller M (1990). Marker-assisted selection of candidate bulls for progeny testing program. Anim. Prod. 51: 63-74.

Kirkpatrick BW (1992). Identification of a conserved microsatellite site in the porcine and bovine insulin-like growth factor-I gene 5' flank. Anim. Genet. 23: 543-548.

Machado MBB, Alencar MM, Pereira AP, Oliveira HN, et al. (2003). QTL affecting body weight in a candidate region of cattle chromosome 5. Genet. Mol. Biol. 26: 259-265.

Marshman E and Streuli CH (2002). Insulin-like growth factors and insulin-like growth factor binding proteins in mammary gland function. Breast Cancer Res. 4: 231-239.

Meuwissen TH and Van Arendonk JA (1992). Potential improvements in rate of genetic gain from marker-assisted selection in dairy cattle breeding schemes. J. Dairy Sci. 75: 1651-1659.

Miller JR, Thomsen PD, Dixon SC, Tucker EM, et al. (1992). Synteny mapping of the bovine IGHG2, CRC and IGF1 genes. Anim. Genet. 23: 51-58.

Miller SA, Dykes DD and Polesky HF (1988). A simple salting out procedure for extracting DNA from human nucleated cells. Nucleic Acids Res. 16: 1215.

Moore KL, Johnston DJ, Graser HU and Herd R (2005). Genetic and phenotypic relationships between insulin-like growth factor-I (IGF-I) and net feed intake, fat, and growth traits in Angus beef cattle. Aust. J. Agric. Res. 56: 211-218.

Ng-Kwai-Hang KF and Grosclaude F (1992). Genetic Polymorphism of Milk Proteins. Vol. 1. In: Advanced Dairy Chemistry (Fox PF, ed.). Elsevier Science Publishers, London, 405-455.

Pagan M, Davis ME, Simmen RCM, Raney NE, et al. (2006). Line and sex association between serum insulin-like growth factor binding proteins (IGFBP) and growth traits of Angus cattle divergently selected for serum IGF-I concentration. J. Anim. Sci. 84 (Suppl 2): 31.

Parmentier I, Portetelle D, Gengler N, Prandi A, et al. (1999). Candidate gene markers associated with somatotropic axis and milk selection. Domest. Anim. Endocrinol. 17: 139-148.

Pereira AP, de Alencar MM, de Oliveira HN and Regitano LCD (2005). Association of GH and IGF-1 polymorphisms with growth traits in a synthetic beef cattle breed. Genet. Mol. Biol. 28: 230-236.

Renaville R (1997). Contribution to Understanding of Some Endocrine Mechanisms Involved in Growth and Lactation. Master's thesis, Gembloux Agricultural University, Gembloux. 
Ribeiro FRB, Carstens GE, Lancaster PA, Tedeschi LO, et al. (2007). Relationships between feed efficiency, carcass and ultrasound traits in Angus beef cattle divergently selected for serum IGF-I concentration. J. Anim. Sci. 85 (Suppl 1): 550.

Rietveld I, Janssen JA, Hofman A, Pols HA, et al. (2003). A polymorphism in the IGF-I gene influences the age-related decline in circulating total IGF-I levels. Eur. J. Endocrinol. 148: 171-175.

Sara VR and Hall K (1990). Insulin-like growth factors and their binding proteins. Physiol. Rev. 70: 591-614.

SAS (Statistical Analysis Systems) (1997). SAS-STAT, User's Guide. SAS Inst. Inc., Cary.

Sorensen MT, Chaudhuri S, Louveau I, Coleman ME, et al. (1992). Growth hormone binding proteins in pig adipose tissue: number, size and effects of pGH treatment on pGH and bGH binding. Domest. Anim. Endocrinol. 9: 13-24.

Spicer LJ, Chase CC Jr and Rutter LM (2002). Relationship between serum insulin-like growth factor-I and genotype during the postpartum interval in beef cows. J. Anim. Sci. 80: 716-722.

Weber MS, Purup S, Vestergaard M, Akers RM, et al. (2000). Regulation of local synthesis of insulin-like growth factor-I and binding proteins in mammary tissue. J. Dairy Sci. 83: 30-37.

Yilmaz A, Davis ME and Simmen RC (2004). Estimation of (co)variance components for reproductive traits in Angus beef cattle divergently selected for blood serum IGF-I concentration. J. Anim. Sci. 82: 2285-2292. 